\title{
HABITS AND PARASITES OF STIGMUS INORDINATUS FOX.
}

\author{
BY A. DAVIDSON, M. D., LOS ANGEles, CAL.
}

Judging from the number of tunnels excavated by this species in soft stemmed plants and friable rock, it must be somewhat common in this vicinity, although on account of the small size and rapid flight it is very seldom seen. The only time I have ever seen it flying was when watching near their excavations, at which time the wasp with its prey may be easily captured. They usually build their cells in tunnels excavated in the stems of the bramble, black mustard, dock, or other pithy plants; but not infrequently they may be found in burrows in the soft sandstone abounding in this district. The plant-stems invariably chosen for a nesting site are those already severed, or broken sufficiently to expose the pith. In the center of this a tunnel of varying depth is excavated. I have a specimen in my possession in which this tiny insect has formed a tunnel 12 inches deep and built and provisioned therein 30 cells. The latter measure on an average one-fourth inch in length by one-sixteenth in width; but both are variable, the width frequently being one-eighth of an inch. This wasp stores its nest with the common aphis, 20 of which are on an average required to provision each cell. The partitions between the cells are composed of pith and vary in thickness. From specimens which I secured in the autumn the mature insects issued in February and March, but the discovery of freshly made cells in February and throughout the summer gives me the impression that while the majority of the adults issue in the spring, yet they are more or less active all the year round, in which respect they are unique among the native hymenoptera of my acquaintance. The larvae spin no cocoons the light yellow pupa lying on its back in the cell. Of the parasites, but two species have been bred thus far; viz.: Omalus iridescens Nort., and a new species of Eurytoma. Of the former only two specimens were reared, from separate cells; both had pupated when discovered in February, and hatched out March I4. Of the Eurytoma, of which a description has been kindly furnished by Mr. Ashmead, a dozen specimens were bred. Each occupied a separate cell which showed no trace of wasp remains; they spun no cocoons, and were about two weeks later in hatching out than the wasps in the same burrows.

Mr. Ashmead's description of the new Eurytoma is as follows:-

\section{Eurytoma stigmi Ashm. n. sp.}

q. Length $3 \mathrm{~mm}$. Black, umbilicately punctate, clothed with sparse white pile; antennae entirely black; apical half of anterior femora, their tibiae, except a black stripe outwardly, and all their tarsi, except the last 
joint, knees of middle and of hind legs and the tips of their tibiae, honey yellow. Wings hyaline, the veins brown, the marginal vein linear but rather stout, twice as long as the stigmal, the post-marginal slender, a little longer than the stigmal. The flagellum is about three and a half times as long as the scape; the funicle 5 -jointed, the first joint the longest, not quite twice as long as thick, the following joints imperceptibly shortening, submoniliform; club 3-jointed, a little longer than the first two funicular joints united, the joints closely conjoined. Thorax as in $E$. diastrophi. Abdomen conically pointed, subcompressed, nearly one-half longer than the head and thorax united, smooth and pol- ished, except segments 6,7 and 9 which are finely shagreened from some microscopic punctures and bearded with white hairs.

8. Length $2.5 \mathrm{~mm}$. Agrees with the $q$ in color, but the funicular joints are incised and pedicellate at tips, the thickened portion being furnished with two whorls of long white hairs, some of which are as long as the joints, the latter very gradually decreasing in length; the club is as long as the first funicular joint, but slenderer; while the body of the abdomen is small, compressed and as viewed from the side triangular in outline attached to the metathorax by a long petiole which is finely sculptured or shagreened and nearly as long as the body of the abdomen.

\title{
PRICKLY LEAF-GALL OF RHODITES TUMIDUS ON ROSA FENDLERI.
}

\author{
BY C. H. TYLER TOWNSEND, BROWNSVILLE, TEXAS.
}

A few miles to the north of Ojo Caliento, on the Hot Springs reserva. tion, in Socorro County, New Mexico, some spherical prickly galls were found in bunches on the leaves of a wild rose, June $\mathrm{r} 8, \mathrm{r} 892$. They were the size of very large peas, reddish and greenish, and covered with prickles One of these galls that was opened Dec. 13, 1892, contained a whitish live hymenopterous pupa, which was somewhat active. This was the pupa of the gall-maker, Rhodites tumidus Bass.

Description of gall.-Diameter 3 to $9 \mathrm{~mm}$. Usual size, 6 to $8 \mathrm{~mm}$. Globular, or subglobular, covered with prickles on upper half, prickles mostly directed upward especially the more superior ones which are from I to It $\mathrm{mm}$. long, those on sides much shorter. Color brick-reddish above, and pea-green below, indicating the surface that has been exposed to the sun and that which has been sheltered therefrom. Growing in bunches, from 2 to 10 in a bunch, rarely singly. Borne always on upper surface of leaf, sometimes three on the same very small leaf which is thus almost obliterated, sometimes borne on petiole of leaf, often double. Gall containing a single large perfectly round cavity, lined with a very thin greenish lining, walls $1 \frac{1}{5} \mathrm{~mm}$. thick in gall of $8 \mathrm{~mm}$. external diameter, leaving cavity about $5 \frac{3}{5} \mathrm{~mm}$. in diameter. Walls porous, minutely cellular, a cross section appearing finely reticulate under lens, the lining of cavity sharing this appearance. The walls average $\mathrm{I} \mathrm{mm}$. in thickness. Each gall contains but a single occupant. The double ones never communicate inside. The gall-fly emerges by a circular hole gnawed in one side of the gall about $1 \frac{1}{2} \mathrm{~mm}$. in diameter.

Described from $3^{8}$ galls. From two of these galls, two gall-flies had 

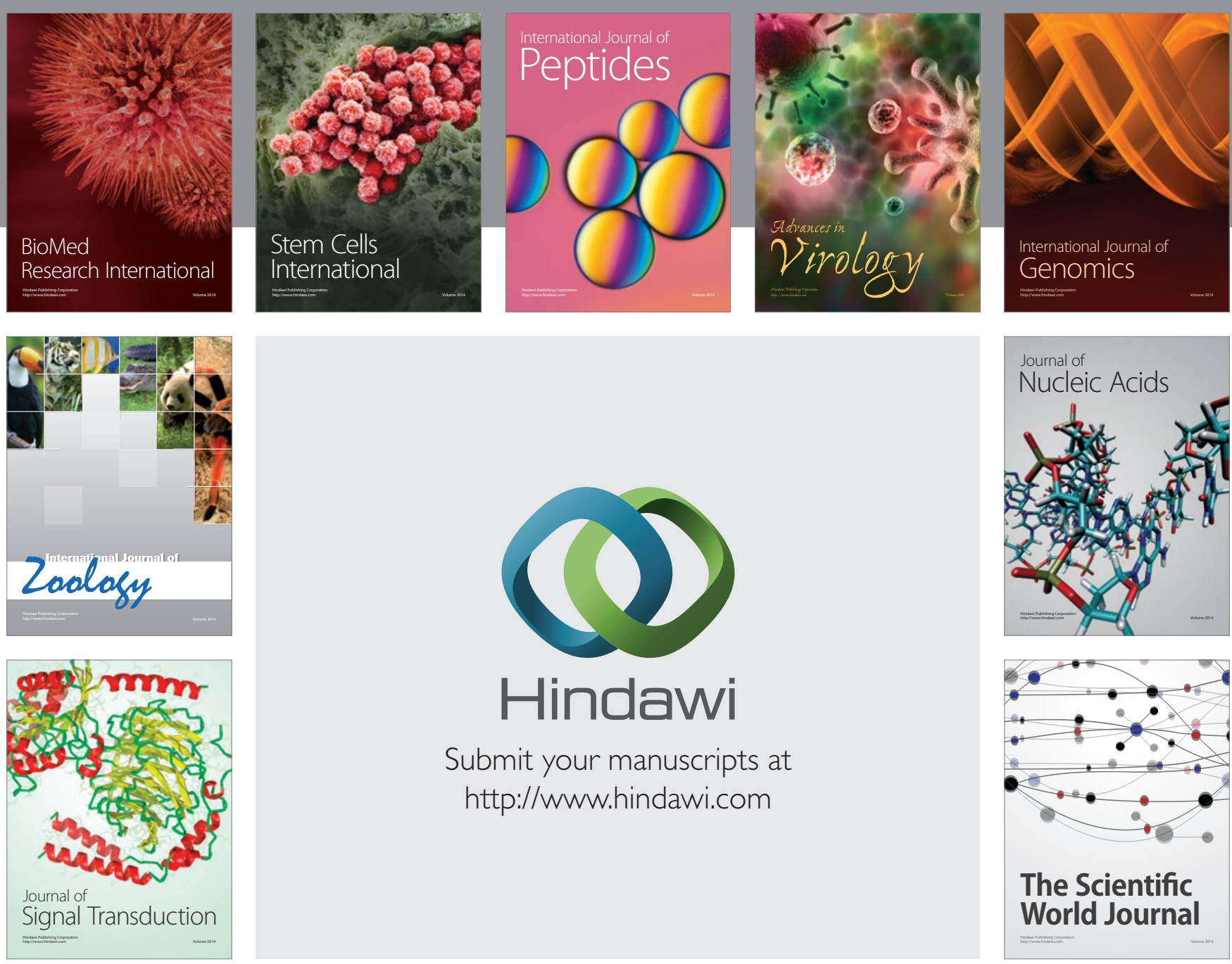

Submit your manuscripts at

http://www.hindawi.com
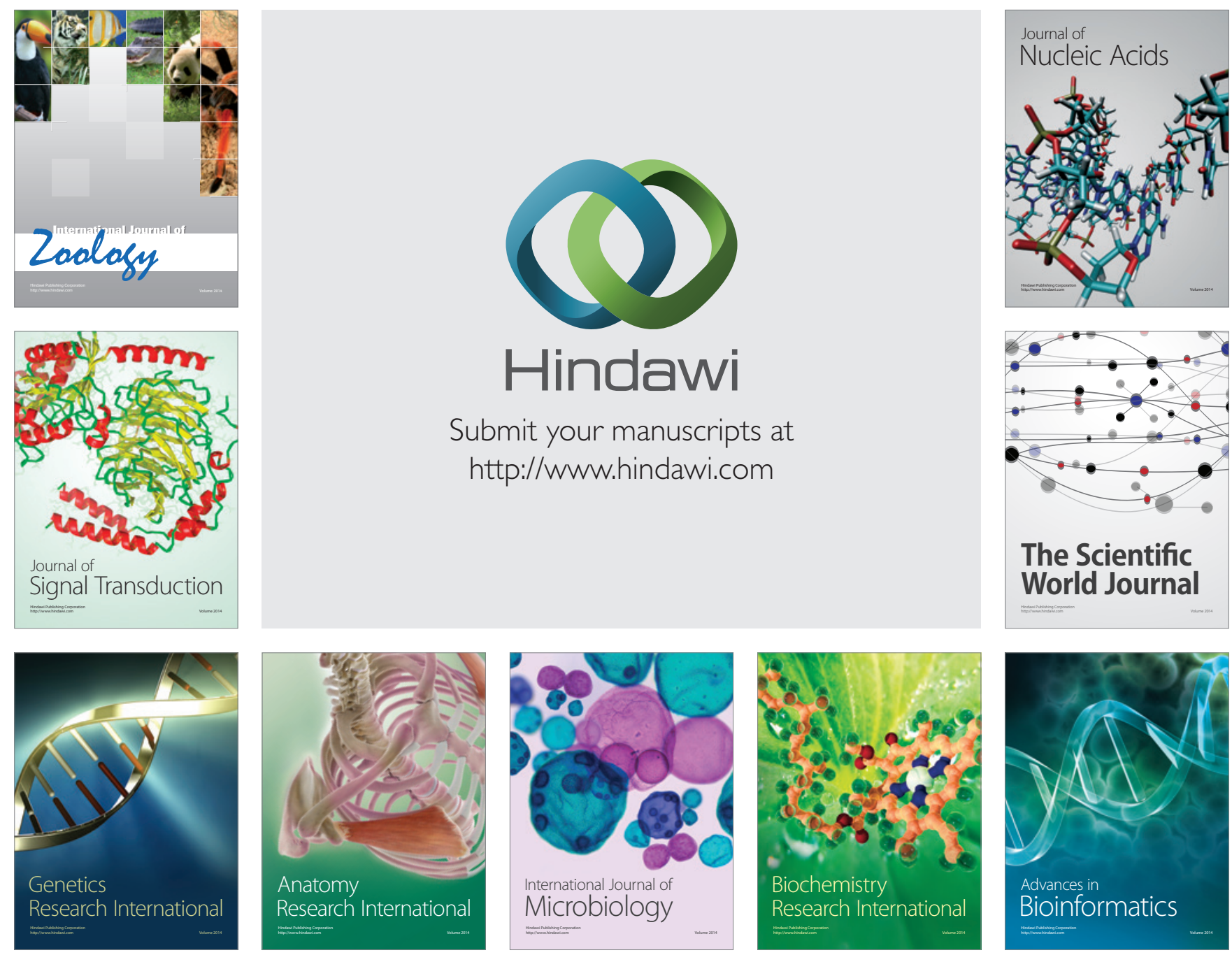

The Scientific World Journal
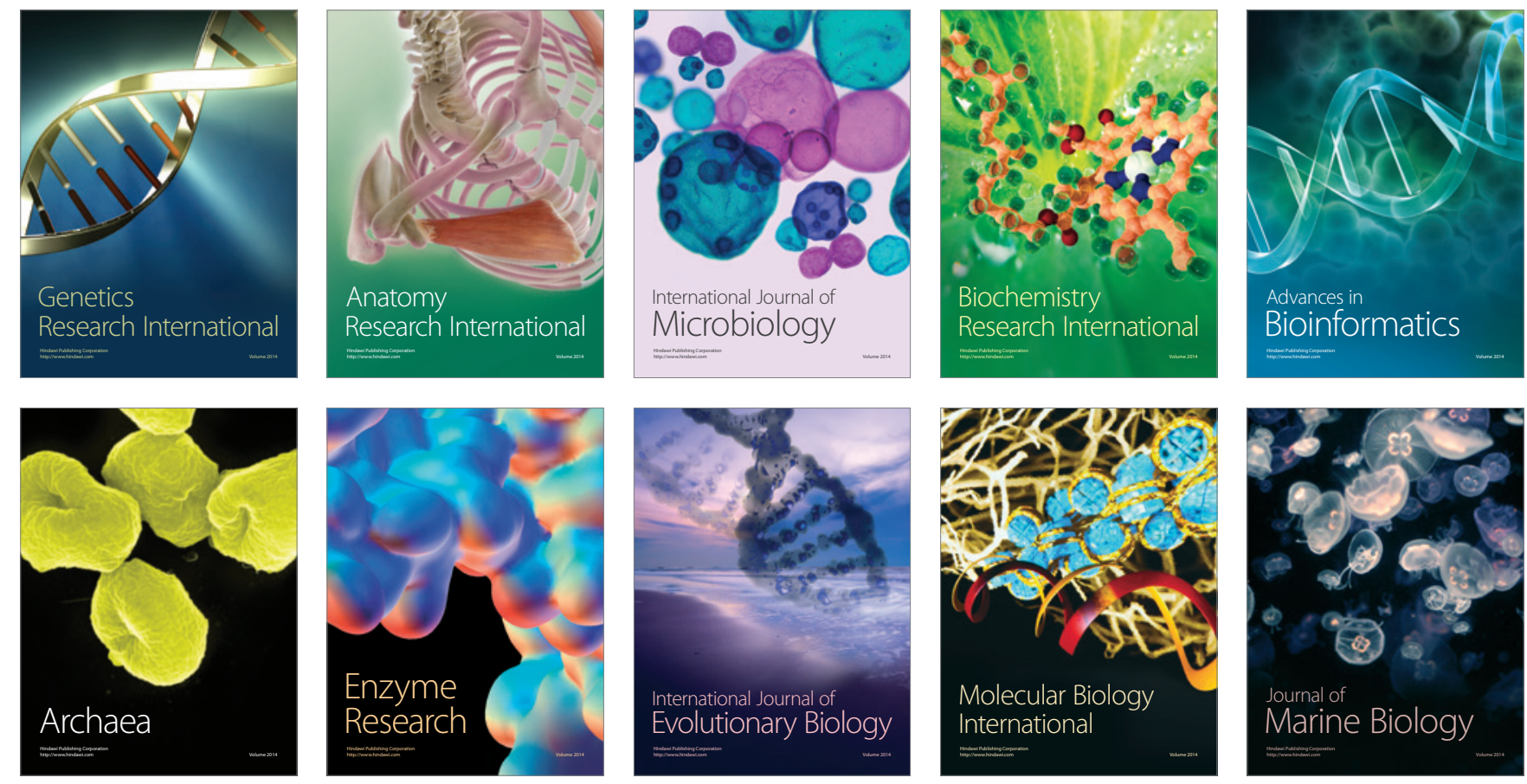